\title{
IMPROVING UNDERSTANDING AND MATHEMATICAL COMMUNICATION LEVEL AND STUDY LEARNING WITH RECIPROCAL TEACHING APPROACH
}

\author{
Iis Yuniar, Euis Eti Rohaeti, Bambang Aryan \\ ${ }^{1,3}$ SMP Negeri 45 Bandung \\ ${ }^{2}$ IKIP Siliwangi Bandung \\ 1iisyuniar71@yahoo.com
}

Received: June, 2018; Accepted: June, 2018

\begin{abstract}
This research is to analyze and analyze the improvement and achievement of students' understanding and communication ability and the independence of junior high school students learning using Reciprocal Teaching approach compared to using ordinary learning. The population in this study is the seventh grade students of SMP in one school in Bandung. The sample of the experimental class and the control class. The method used in this research is quasi experiment. Data processing of communication skills and mathematical understanding using $\mathrm{t}$-test, two-lane anova and linear regression. The result of the research shows that the achievement and improvement of students' mathematical understanding and communication ability which get the learning using Reciprocal Teaching approach is better than the students who get regular learning. Students of experimental class with Reciprocal Teaching learning and control class with ordinary learning there is no relation between mathematical understanding ability with student learning independence and experimental class students with Reciprocal Teaching lesson and control class with ordinary learning there is no correlation between mathematic communication ability with student learning independence.
\end{abstract}

Keywords: Mathematical Understanding, Mathematical Communication, Student Learning Independence, Reciprocal Teaching Approach

\begin{abstract}
Abstrak
Penelitian ini untuk menelaah dan menganalisis peningkatan dan pencapaian kemampuan pemahaman dan komunikasi matematik siswa serta kemandirian belajar siswa SMP yang pembelajarannya menggunakan pendekatan Reciprocal Teaching dibandingkan dengan yang menggunakan pembelajaran biasa. Populasi dalam penelitian ini adalah siswa kelas VII SMP pada salah satu sekolah di Kota Bandung. Sampel kelas eksperimen dan kelas kontrol. Metode yang digunakan dalam penelitian ini adalah kuasi eksperimen. Pengolahan data kemampuan komunikasi dan pemahaman matematik menggunakan uji-t, anova dua jalur dan regresi linear. Hasil penelitian menunjukkan pencapaian dan peningkatan kemampuan pemahaman dan komunikasi matematik siswa yang memperoleh pembelajaran dengan menggunakan pendekatan Reciprocal Teaching lebih baik daripada siswa yang memperoleh pembelajaran biasa. Siswa kelas eksperimen dengan pembelajaran Reciprocal Teaching dan kelas kontrol dengan pembelajaran biasa tidak terdapat kaitan antara kemampuan pemahaman matematik dengan kemandirian belajar siswa dan siswa kelas eksperimen dengan pembelajaran Reciprocal Teaching dan kelas kontrol dengan pembelajaran biasa tidak terdapat kaitan antara kemampuan komunikasi matematik dengan kemandirian belajar siswa.
\end{abstract}

Kata Kunci: Pemahaman Matematik, Komunikasi Matematik, Kemandirian Belajar Siswa, Pendekatan Reciprocal Teaching 

Communication Skills and Junior High School Student Self-Reliance with Reciprocal Teaching Approach

How to Cite: Yuniar, I., Rohaeti, E. T., Aryan, B. (2018). Improving Mathematical Understanding and Communication Skills and Junior High School Student Self-Reliance with Reciprocal Teaching Approach. JIML, 1 (2), 59-66.

\section{INTRODUCTION}

Understanding the concept of mathematics is one of the capital for students to solve various problems contained in mathematics, students can inform, solve problems. And the ability of mathematical understanding is one of the objectives of learning, where students should be more understanding of the concept of the subject matter itself. Furthermore, according to Wulandari, $\mathrm{T}$ (2017) suggests that the achievement and improvement of students' math under standing skills learn to use contextual approach is better than students who learn with the usual approach. In addition to understanding in the process of learning mathematics, communication skills are required. Students should be able to interpret, express ideas, and inform what is in the problems gained in learning mathematics.

Based on the results of the observation of the writer in the field of the ability of understanding the concept of mathematics and student communication is very less, students have not been able to apply or apply it into mathematical problems. As revealed by This, in line with Hilman's research, BM (2017) argues that the achievement and improvement of the mathematical communication ability of junior high school students whose learning using reciprocal teaching approach is better than that of learning using ordinary learning reviewed entirely by TKAS (low, high).

Independence is very important because independence is a personal attitude that is needed by every individual. As revealed by Sumarmo, U (2004), that with Independence, students tend to learn better, be able to monitor, evaluate, and manage their learning effectively, save time efficiently, be able to direct and control themselves in thinking and acting, do not feel dependent on others emotionally. Students who have the independence of learning are able to analyze complex problems, able to work individually or in collaboration with groups, and dare to express ideas. From the description above, the ability of understanding mathematics, mathematics communication and student learning independence are some factors that can determine the success of student learning in learning mathematics. The diversity of learning methods or current learning approaches requires educators to be more precise in choosing learning methods and classroom approaches, in order to maximize their outcomes. The learning process is no longer teacher-centered, but centered on students, in which case students are directly involved in exploring and seeking new knowledge. To that end teachers no longer use traditional methods or lectures, writing, giving formulas to their students. With the method of lecturing involvement of students in the learning process is very limited, consequently the ability of mathematical understanding, communication skills and independence of junior high school students to be less satisfactory. That's the reason why the writer tries to apply the Reciprocal Teaching approach (reverse) in class. Reciprocal Teaching approach method involves many students actively in the process of learning in the classroom. Through this reverse learning is expected to understand the concept of mathematics students develop (increase) and students are able to apply the concept of mathematics. With this reversed lea rning the students learn how to read the teaching materials materials, summarize the teaching materials, compile questions, predict and solve them, explain the knowledge they gain, and make further questions of the problems given to the students. Learning Strategy Reciprocal 
Teaching is a constructivism approach based on the principles of making / asking questions (Trianto, 2007: 96).

Meanwhile, according to Palincsar and Brown (1984: 117-175), the reciprocal teaching strategy is a constructivist approach based on the principles of questioning, teaching metacognitive skills through teaching, and modeling by teachers to improve reading skills in low-ability students. Reciprocal Teaching is a learning approach that employs four independent strategies of understanding, concluding instructional materials, compiling questions and solving them, reexplaining the knowledge it has acquired, then predicting further questions of issues presented to students. This is in line with Rachmayani, D (2014) Journal of Research article entitled "Application of Reciprocal Teaching Lessons to Improve Mathematical Communication Skill and Student Learning Mathematics Independence". In this research show Achievement and improvement of ability of understanding and ability of mathematic communication of junior high school student whose learning using Reciprocal Teaching is better than learning using ordinary learning in terms of student's initial ability. Basically Reciprocal Teaching emphasizes the cooperation of students in a group that is formed so that each member can communicate comfortably in expressing opinions or inquires in order to exchange experiences of learning success with each other. Based on the above description the authors feel interested in doing research with the title Increase the ability of Understanding and Communication Mathematics and Self-Reliance Learning Junior High School with Reciprocal Teaching Approach.

\section{METHOD}

The method used in this study is a quasi-experimental method with pretest-postes control group design. This study was conducted on students from two classes with different approaches. The first group is an experimental class that receives learning with a reciprocal teaching approach, while the second group is a control class that obtains regular learning. Both classes will be given pretest and postes to review the learning with reciproca teaching approach to the achievement and improvement of comprehension ability and mathematical communication ability in one of junior high school in Bandung. The design of this research is as follows: Ruseffendi, E.T. (2005)

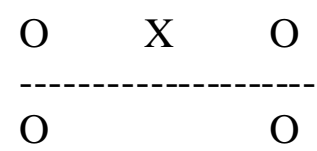

with:

---- = class sampling is not random

$\mathrm{O}=$ pretes $/$ postes the ability of mathematical communication, understanding ability and independence

$\mathrm{X}$ = learning with reciprocal teaching approach

The population of this study is all students of class VII one of the SMP Negeri in Bandung year 2017-2018 school year. It is for the reason that the school is in the middle category in terms of students' abilities. While the sample of this research is two class VII that is for experiment class and control class. One class for experimental learning using reciprocal teaching approach and a control class with ordinary learning. The data were processed through normality test, homogeneity test, and two average difference test, two-track anova test and linear regression test using SPSS version 21.0 for Windows software. 
62 Yuniar, I., Rohaeti, E. T., Aryan, B. Improving Mathematical Understanding and Communication Skills and Junior High School Student Self-Reliance with Reciprocal Teaching Approach

\section{RESULTS AND DISCUSSION}

\section{Results}

The results of research for the ability of mathematical understanding are as follows:

Table 1. Data Analysis Postes and N-Gains for Achievement and Improvement of Student Mathematical Understanding Ability

\begin{tabular}{|c|c|c|c|c|c|c|c|c|}
\hline \multirow{2}{*}{$\begin{array}{c}\text { Testing } \\
\text { Data }\end{array}$} & \multirow[b]{2}{*}{ Class } & \multirow{2}{*}{$\begin{array}{c}\text { Normalit } \\
\mathrm{y}\end{array}$} & \multirow{2}{*}{$\begin{array}{l}\text { Homogen } \\
\text { eity }\end{array}$} & \multicolumn{3}{|c|}{ Two way anova } & \multicolumn{2}{|c|}{ Interaction } \\
\hline & & & & $\begin{array}{l}\text { Meth } \\
\text { od }\end{array}$ & $\begin{array}{c}\text { TKA } \\
\text { S }\end{array}$ & $\begin{array}{l}\text { Method } \\
\text { *TKAS }\end{array}$ & $\begin{array}{l}\text { Schef } \\
\text { fe }\end{array}$ & Info. \\
\hline \multirow{2}{*}{$\begin{array}{c}\text { Postes } \\
\text { Understand } \\
\text { ing }\end{array}$} & Experiment & 0.200 & 0.854 & \multirow{2}{*}{0.000} & \multirow{2}{*}{0.862} & \multirow{2}{*}{0.189} & \multirow{2}{*}{ - } & \multirow{2}{*}{$\begin{array}{c}\text { No there } \\
\text { is }\end{array}$} \\
\hline & Control & 0.055 & 0.854 & & & & & \\
\hline \multirow{2}{*}{$\begin{array}{c}\text { N-Gain } \\
\text { Understand } \\
\text { ing }\end{array}$} & Experiment & 0.112 & 0.864 & \multirow{2}{*}{0.000} & \multirow{2}{*}{0.680} & \multirow{2}{*}{0.228} & \multirow{2}{*}{ - } & \multirow{2}{*}{$\begin{array}{c}\text { No there } \\
\text { is }\end{array}$} \\
\hline & Control & 0.050 & 0.864 & & & & & \\
\hline
\end{tabular}

The result of the research shows that the achievement and improvement of students' mathematical comprehension ability whose learning using reciprocal teaching is better than the learning using ordinary learning in terms of the students' initial ability level and there is no interaction between reciprocal teaching and the level of students' initial ability in generating mathematical understanding ability.

After the two-lane anova test proved that the most important role in achieving and improving the ability of mathematical understanding is the learning method of reciprocal teaching, but the level of initial ability of students is not so instrumental in achieving and improving students' mathematical understanding ability.

And because there is no interaction between learning methods with the level of initial ability of students in generating students' mathematical understanding skills then not proceed to the Scheffe Test.

Meanwhile, the results of research for mathematical communication ability are as follows:

Table 2 Analysis of Postes and N-Gain Data for Achieving and Improving Student Mathematical Communication Skill

\begin{tabular}{|c|c|c|c|c|c|c|c|c|}
\hline \multirow[b]{2}{*}{$\begin{array}{c}\text { Testing } \\
\text { Data }\end{array}$} & \multirow[b]{2}{*}{ Class } & \multirow[b]{2}{*}{$\begin{array}{c}\text { Normalit } \\
\mathrm{y}\end{array}$} & \multirow[b]{2}{*}{$\begin{array}{l}\text { Homogen } \\
\text { eity }\end{array}$} & \multicolumn{3}{|c|}{ Two way anova } & \multicolumn{2}{|c|}{ Interaction } \\
\hline & & & & $\begin{array}{l}\text { Meth } \\
\text { od }\end{array}$ & $\begin{array}{c}\text { TKA } \\
\mathrm{S}\end{array}$ & $\begin{array}{l}\text { Method } \\
\text { *TKAS }\end{array}$ & $\begin{array}{l}\text { Schef } \\
\text { fe }\end{array}$ & Info. \\
\hline \multirow{2}{*}{$\begin{array}{c}\text { Postes } \\
\text { Communic } \\
\text { ation }\end{array}$} & Experiment & 0.059 & 0.757 & \multirow{2}{*}{0.007} & \multirow{2}{*}{0.233} & \multirow{2}{*}{0.913} & \multirow{2}{*}{-} & \multirow{2}{*}{$\begin{array}{l}\text { No there } \\
\text { is }\end{array}$} \\
\hline & Control & 0.088 & 0.757 & & & & & \\
\hline \multirow{2}{*}{$\begin{array}{c}\mathrm{N}-\text { Gain } \\
\text { Communic } \\
\text { ation }\end{array}$} & Experiment & 0.070 & 0.610 & \multirow{2}{*}{0.301} & \multirow{2}{*}{0.247} & \multirow{2}{*}{0.899} & \multirow[b]{2}{*}{-} & \multirow{2}{*}{$\begin{array}{c}\text { No there } \\
\text { is }\end{array}$} \\
\hline & Control & 0.053 & 0.610 & & & & & \\
\hline
\end{tabular}

The results showed that the achievement and improvement of students' mathematical communication ability using the reciprocal teaching learning better than the learning using normal learning in terms of the students' initial ability level and there is no interaction between reciprocal teaching and the level of students' initial ability in producing mathematical communication skills. 
After the two-lane anova test proved that the most important role in the achievement and improvement of mathematical communication skills is the learning method of reciprocal teaching, but the level of initial ability of students is not so instrumental in achieving and improving students' mathematical communication skills.

And because there is no interaction between the learning method with the level of initial ability of students in generating students' mathematical communication skills then not proceed to the Scheffe Test.

The results of the study for student self-reliance are as follows:

Table 3. Data Analysis Student Self Regulated Scale

\begin{tabular}{ccccc}
\hline \multirow{2}{*}{ Testing Data } & Class & Normality & Homogeneity & $\begin{array}{c}\text { Two-point } \\
\text { Differences }\end{array}$ \\
\hline \multirow{2}{*}{$\begin{array}{c}\text { Self } \\
\text { Regulated }\end{array}$} & Experiment & 0.158 & 0.000 & 0.000 \\
\cline { 2 - 3 } & Control & 0.075 & 0.000 & \\
\hline
\end{tabular}

The results showed that students' learning independence in learning using reciprocal teaching is better than that of learning using ordinary learning in terms of initial ability level of students The results of the research for Regression and Correlation Analysis are as follows:

Table 4. Regression and Correlation

\begin{tabular}{|c|c|c|c|c|c|c|c|}
\hline Asosiasion & Normality & & Regression & Correlation & Guilford & Significance & Info. \\
\hline \multirow{2}{*}{$\begin{array}{l}\text { Understanding- } \\
\text { Communication }\end{array}$} & Understanding & 0.200 & \multirow{2}{*}{0.283} & \multirow{2}{*}{ - } & \multirow{2}{*}{ - } & \multirow{2}{*}{ - } & \multirow{2}{*}{$\begin{array}{l}\text { No } \\
\text { there is }\end{array}$} \\
\hline & Communication & 0.059 & & & & & \\
\hline \multirow{2}{*}{$\begin{array}{l}\text { Understanding } \\
\text {-Self Regulated }\end{array}$} & Understanding & 0.200 & \multirow[b]{2}{*}{0.428} & \multirow[b]{2}{*}{ - } & \multirow[b]{2}{*}{ - } & \multirow[b]{2}{*}{$\begin{array}{ll}- & \text { r }\end{array}$} & \multirow{2}{*}{$\begin{array}{l}\text { No } \\
\text { there is }\end{array}$} \\
\hline & Self Regulated & 0.075 & & & & & \\
\hline \multirow{2}{*}{$\begin{array}{c}\text { Communication } \\
\text { - Self } \\
\text { Regulated }\end{array}$} & Communication & 0.059 & \multirow{2}{*}{0.601} & \multirow[b]{2}{*}{ 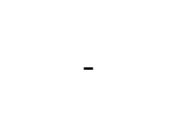 } & \multirow[b]{2}{*}{ 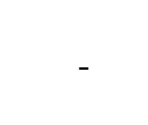 } & \multirow[b]{2}{*}{ 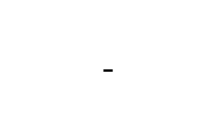 } & \multirow{2}{*}{$\begin{array}{l}\text { No } \\
\text { there is }\end{array}$} \\
\hline & Self Regulated & 0.075 & & & & & \\
\hline
\end{tabular}

The result of the research shows that there is no correlation between understanding comprehension and mathematical communication, mathematical understanding and learning independence and between mathematical communication and student learning independence either in class using reciprocal teaching or in class using ordinary learning.

\section{Discussion}

From the results of data processing is seen that the reciprocal teaching effect on students' mathematical understanding ability. For the achievement of the ability of mathematical understanding is seen based on the method of learning that learning using reciprocal teaching in learning mathematics helps in achieving students' mathematical reasoning abilities. Meanwhile, if viewed based on TKAS that there is no significant difference between students' mathematical understanding ability on certain TKAS. To improve the ability of mathematical understanding is seen based on learning method that learning using reciprocal teaching in learning mathematics helps in improving students' mathematical understanding ability.

Meanwhile, if viewed based on TKAS that there is no significant difference between students' mathematical understanding ability on certain TKAS. From the results of data processing is seen that the reciprocal teaching effect on students' mathematical communication skills. For the 
achievement of mathematical communication ability is seen based on learning method that learning using reciprocal teaching in learning mathematics assist in achieving students' mathematical communication ability. Meanwhile, if viewed based on TKAS that there is no significant difference between students' mathematical communication skills on certain TKAS. To improve the ability of mathematical communication is seen based on learning method that learning using reciprocal teaching in learning mathematics does not help in improving students' mathematical communication skills. Meanwhile, if viewed based on TKAS that there is no significant difference between students' mathematical communication abilities in TKAS certain. From the results of data processing is seen that the reciprocal teaching effect on student learning independence. Student learning independence is seen based on the method of learning that learning using reciprocal teaching in learning mathematics does not help in developing student self-reliance.

From result of data processing seen that there is no significant influence from students' mathematical understanding ability to their mathematical communication ability. Because there is no significant influence of students' mathematical understanding on mathematical communication ability then it is not continued to correlation test. From the result of data processing, it can be seen that there is no significant influence from students' mathematical understanding ability to their learning independence. Because there is no significant influence of the students 'mathematical understanding ability on the ability of self-reliance learning then it is not continued to correlation test and from result of data processing seen that there is no significant influence from students' mathem atical communication ability to their independence learning ability. Because there is no significant influence of the students' mathematical communication ability on the independence of learning then it is not continued to the correlation test. From the data processing, it can be seen that there is no interaction between reciprocal teaching approach with students 'mathematical comprehension ability, communication ability and students' self-reliance either on high, medium or low TKAS.

Based on the instrument of students 'responses on reciprocal teaching by giving a questionnaire of students' perceptions of reciprocal teaching obtained from the students 'answers indicates that in the developed learning, the students' motivation in learning is high, so they are willing to discuss and work hard in solving the problems given. Students who are the subject of this research generally have a positive attitude toward learning mathematics. Reciprocal teaching can contribute to developing students' mathematical understanding and communication skills compared to ordinary learning. This can be seen from the answers of students who express more like learning as given and they are helped to think critically. In addition, students are more enthusiastic and enthusiastic about working on problems on LKS and postes questions. From the calculation that the average pretest score of mathematical comprehension ability, the experimental class is lower than the control class.

However, in the postes result, the average postes score of the students' understanding of experimental mathematical ability is higher than the control class. And the average pretest and postes score of mathematical communication ability, the experimental class is higher than the control class. Overall the results of pretest and postes both for the ability of mathematic pemahmana and for the ability of mathematical communication has almost reached the maximum score.

\section{CONCLUSION}

Based on the analysis of data and discussion presented in the previous Chapter, obtained some conclusions as follows: The achievement and improvement of the ability of mathematical understanding of junior high school students whose learning using reciprocal teaching is better 
than the learning using ordinary learning in terms of the initial ability of the students. The achievement and improvement of mathematic communication ability of junior high school students whose learning using reciprocal teaching is better than the learning using ordinary learning in terms of students' initial ability.

The independence of mathematics learning of vocational students whose learning using reciprocal teaching is better than that of learning using ordinary learning in terms of initial ability of students. There is no correlation between the ability of understanding and mathematical communication of junior high school students in both classes using reciprocal teaching as well as in classes using ordinary learning. There is no correlation between the ability of mathematical understanding and learning independence of junior high school students in both classes using reciprocal teaching as well as in classes using ordinary learning. There is a correlation between mathematical communication ability and learning independence of junior high school students in both classes using reciprocal teaching as well as in classes using ordinary learning. There is no interaction between reciprocal teaching and the student's early ability level in generating mathematical understanding skills. There is no interaction between reciprocal teaching and the students' initial ability to produce mathematical communication skills. There is no interaction between reciprocal teaching and the level of initial ability of students in generating student self-reliance.

The picture of student's performance during reciprocal teaching on the developed learning looks high student's motivation in learning, so they want to discuss and work hard in solving the given problem. Students who are the subject of this research generally have a positive attitude toward learning mathematics. Reciprocal teaching can contribute to developing students' mathematical understanding and communication skills compared to ordinary learning. This can be seen from the answers of students who express more like learning as given and they are helped to think critically. In addition, students are more enthusiastic and enthusiastic about working on problems on LKS and posttest questions. Description of student performance in solving problems Overall the results of pretest and posttest both for the ability of mathematic and for the ability of mathematical communication has almost reached the maximum score.

\section{REFERENCES}

Hilman, B.M. ( 2017). Meningkatkan Kemampuan Komunikasi Dan Koneksi Matematik Serta Disposisi Matematis Siswa Dengan Menggunakan Metode Reciprocal Teaching : Tesis pada STKIP Siliwangi Bandung. Tidak diterbitkan.

Palincsar A.S dan Brown A.(1984).(Reciprocal Teaching Of Comprehension Fostering And Comprehension Mentoring Activities). Cognition And Instruction.1(2): 117-175. [Online].Tersedia:www.Moc.go.jm/projects/newhorizons/pdf/specific\%20readingteac hing\%20strategi-es/reciprocal\%20teahing.pdf [ 8 Maret 2008].

Rachmayani, D ( 2014 ). Penerapan Pembelajaran Reciprocal Teaching Untuk Meningkatkan Kemampuan Komunikasi Matematik Dan Kemandirian Belajar Matematika Siswa. Vol 2 No. 1 [Online]. Tersedia : https://www.scribd.com/document/363341076/2-ArtikelJurnal-Dwi-Rahmayani-Matematika-pdf, Universitas Muhamadiyah Jakarta [November 2014]

Ruseffendi, E.T. (2005). Dasar Dasar Penelitian Pendidikan dan Bidang Non Eksakta Lainnya. Bandung: Tarsito. 
66 Yuniar, I., Rohaeti, E. T., Aryan, B. Improving Mathematical Understanding and Communication Skills and Junior High School Student Self-Reliance with Reciprocal Teaching Approach

Sumarmo, U. (2004d). Kemandirian Belajar: Apa, Mengapa, dan Bagaimana Dikembangkan pada Peserta Didik. Makalah pada Seminar Tingkat Nasional. FPMIPA UNY Yoggyakarta. [8 Juli 2004]

Trianto. (2007). Model-model Pembelajaran Inobatif Berorientasi Konstruktivistik. Jakarta: Prestasi Pustaka

Wulandari, T(2017). Meningkatkan Kemampuan Pemahaman dan komunikasi Matematik Serta Kemandirian Belajar Siswa Melalui Pendekatan Kontekstual : Tesis pada STKIP Siliwangi Bandung. Tidak diterbitkan. 